Revista Española de Antropología Americana ISSN: 0556-6533

https://doi.org/10.5209/REAA.63690

\title{
Exploraciones alrededor de la relación entre personas y objetos rituales en las celebraciones populares de los Reyes Magos en Brasil
}

\author{
Daniel Bitter ${ }^{1}$
}

Recibido: 3 de abril de 2017 / Aceptado: 10 de octubre de 2018

Resumen. En este artículo, se reflexiona sobre los usos sociales y simbólicos de objetos rituales en el contexto de la folia de reis, una fiesta popular dedicada a los Reyes Magos, que ocurre en gran parte del territorio brasileño, en el que hombres, mujeres, niños, jóvenes y ancianos participan intensamente en grandes redes de reciprocidad social. El estandarte es un soporte material utilizado por los participantes en sus peregrinaciones rituales y en el cual se fijan imágenes de santos católicos. Alrededor del estandarte se establece un intenso campo de interacciones y acciones. Su importancia se puede expresar en la creencia de que el estandarte posee poderes supra-mundanos, que traen bendiciones y dádivas al destinatario. La máscara, a su vez, es utilizada por un personaje clave de las fiestas conocido como payaso. Es un tipo liminal, cómico y ambiguo, y su máscara de apariencia grotesca adquiere significados moralmente negativos, en contraste con el estandarte. Objetivos y subjetivos, materiales e inmateriales, tales objetos se caracterizan, al fin y al cabo, por ser ambivalentes, pues realizan mediaciones entre dominios naturales, sociales y cósmicos.

Palabras clave: ritual; fiestas; Reyes Magos; objetos materiales

\section{[en] Explorations around the Relationship between People and Ritual Objects in Popular Celebrations of the Three Kings in Brazil}

\begin{abstract}
In this article, I propose to reflect on the social and symbolic uses of ritual objects in the context of folia de reis, a festive enterprise that occurs in much of Brazil devoted to the Three Kings, where men, women, children, young people and the elderly are intensely involved in wide webs of social reciprocities. The banner is a sacred object transported by attendants in their ritual pilgrimages, on which are fixed images of Catholic saints. Around the banner, an intense field of interactions and agencies are established. Its importance can be summed up in the belief that it holds super-mundane powers, bringing blessings and thanks to those who receive it. The mask, in turn, is used by a key character of these festivities known as palhaço. It is a markedly liminal type, comic and ambiguous, and its mask, of grotesque appearance, assumes morally negative meanings in contrast to the banner. Simultaneously objective and subjective, material and immaterial, these objects are characterized, after all, by being deeply ambivalent, realizing mediations between the natural, social and cosmic domains.
\end{abstract}

Keywords: ritual; festivities; Three Kings; material objects

Sumario. 1. Introducción. 2. El circuito ritual de la folia de reis 3. El estandarte, sus usos y significados. 4. La máscara y su liminalidad. 5. Consideraciones finales. 6. Referencias.

Cómo citar: Bitter, Daniel. 2018. «Exploraciones alrededor de la relación entre personas y objetos rituales en las celebraciones populares de los Reyes Magos en Brasil». Revista Española de Antropología Americana 48: 65-78.

\footnotetext{
1 Universidade Federal Fluminense, Brasil. danielbitter@gmail.com
} 


\section{Introducción}

Las folias de reis son manifestaciones extendidas en gran parte del territorio brasileño, con numerosas variantes y denominaciones. Se definen como grupos de plegaria compuestos por cantantes y actores que llevan a cabo visitas a las casas de los devotos distribuyendo bendiciones e intercambiándolas por ofertas destinadas a promover una gran fiesta en honor a los Reyes Magos de Oriente: Melchor, Gaspar y Baltasar. De este modo, las folias buscan recrear el viaje mítico de los Reyes Magos a Belén, guiados por una estrella divina, para adorar y dar regalos al niño Jesús. Alrededor de las folias, hombres, mujeres, ancianos e incluso niños y niñas participan en las redes de reciprocidad moral, reafirmando periódicamente lazos sociales de parentesco, amistad, vecindad, etc. El lugar de los devotos dentro de este sistema es extremadamente importante, ya que comparten con los foliões -los integrantes del ritual festivo- ciertas creencias y conocimientos rituales involucrados en tales intercambios de regalos y contra-regalos.

Este rito popular moviliza diversas categorías sociales, deidades y antepasados en intercambios profundos y significativos, a través de los cuales se crean vínculos sociales y cosmológicos, fortaleciendo un extenso y complejo sistema de prestaciones recíprocas (Mauss 2003).

Desde el año 2004 he realizado trabajo de campo sobre folias de reis en varios lugares del estado de Río de Janeiro, concentrándome en la colina de la Candelaria, una de las subregiones del Complejo de Mangueira, al norte de la ciudad de Río de Janeiro. En esta localidad me he acercado a las acciones rituales de los miembros de la Folia de Reis Sagrada Família. Después de ser invitado por el maestro de la folia a unirme al grupo mediante el rol de músico, empecé a realizar mis observaciones como participante, lo que produjo un cambio significativo en la calidad de las relaciones con mis interlocutores.

La Candelaria se formó alrededor del año 1940, cuando el área fue ocupada principalmente por familias migrantes de las zonas rurales de la provincia de Minas Gerais y de la provincia de Río de Janeiro, y actualmente alberga unos tres mil habitantes. Los migrantes han actualizado la memoria de los ritos y las fiestas dedicadas a los Reyes Magos. En Candelaria, un modo específico de sociabilidad se desarrolla a partir de relaciones de parentesco y vecindad: los familiares viven como vecinos y estos lo hacen como parientes. En este contexto, las fiestas de reyes parecen asumir una importancia significativa en el fortalecimiento de los vínculos sociales y en la creación de nuevas relaciones en un contexto marcado por el proceso de migración.

A menudo, las folias se originan debido al pago de una promesa por la gracia recibida. La categoría promesa asume, por lo tanto, un rol fundamental en las relaciones de compromiso y de intercambios (Mauss 2003). Sin embargo, debo llamar la atención sobre el hecho de que estos circuitos de intercambios son acontecimientos peligrosos, ya que al establecer vínculos con las deidades y los antepasados, interactúan concretamente con fuerzas incontrolables, con incertidumbres y expectativas (Bourdieu 1996). El maestro de la folia asume el papel ritual jerárquicamente más alto, pero depende de la ayuda de las otras personas para cumplir su promesa. El maestro es quien tiene el conocimiento ritual necesario para dirigir al grupo, responsabilizándose por sus condiciones materiales. Además del maestro, la folia está compuesta por el contramestre, portaestandarte, cantantes, payasos y actores en su estructura organizativa. Son hombres y mujeres de edades muy diferentes que ejer- 
cen una variedad de actividades en la vida diaria: estudiantes, porteros, técnicos, mecánicos, etc. Los niños de vez en cuando también toman parte de estos rituales, lo que señala formas de reproducción y continuidad de estas prácticas.

La Folia Sagrada Familia realiza un largo circuito de visitas a las casas de los devotos. Las llamadas «jornadas» tienen lugar desde el 25 de diciembre hasta el 20 de enero, de preferencia los fines de semana, y constituyen un importante período de ritos preparatorios para la celebración de la fiesta de arremate, con la cual se culmina el ciclo ritual. En cada día de «jornada» se visitan alrededor de ocho a doce casas, lo que totaliza, al final de un ciclo entero, cerca de 45 casas visitadas e involucra a aproximadamente 150 personas. Estas visitas también se hacen fuera de la Candelaria en regiones más distantes, como Morro Chapéu Manguera en la zona sur de la ciudad, o Vila Cruzeiro, en el barrio de Penha, lo que revela una amplia red de relaciones sociales. Por último, el circuito de visitas culmina con la divulgación de la fiesta de arremate, una ceremonia grande y ostentosa celebrada en agradecimiento a la comunidad de devotos por la receptividad y las donaciones ofrecidas, las cuales pasan entonces de su acumulación a su redistribución ceremonial.

En estos rituales, dos objetos materiales ocupan un elevado lugar de centralidad: el estandarte de los santos Reyes Magos y la máscara del payaso. El estandarte es un soporte material transportado por los folioes en sus caravanas rituales y en cuya superficie son sujetadas y exhibidas imágenes de santos católicos. Alrededor del estandarte se establece un intenso campo de interacciones y agenciamientos. Su importancia se puede resumir en la creencia de que el estandarte posee poderes supramundanos, trayendo bendiciones y dádivas al destinatario. La máscara, a su vez, es utilizada por un personaje clave de las fiestas conocido como payaso. Es un tipo liminal, cómico y ambiguo, y su máscara de apariencia grotesca adquiere significados moralmente negativos en contraste con el estandarte. Simultáneamente objetivos y subjetivos, materiales e inmateriales, tales objetos se caracterizan, después de todo, por ser profundamente ambivalentes, pues realizan mediaciones entre dominios naturales, sociales y cósmicos.

El objetivo principal de este artículo es hacer algunas exploraciones de los usos sociales y simbólicos de estos objetos, a partir de observaciones etnográficas.

\section{El circuito ritual de la folia de reis}

Como se ha observado en muchas ocasiones, las «jornadas» comienzan cuando el portaestandarte, ayudado por el maestro y en presencia de otros foliões, retira el estandarte del altar y ejecuta a continuación una serie de acciones rituales, que incluyen el canto de versos y oraciones. El estandarte permanece guardado, durante todo el año, dentro de un altar privado, cuidadosamente preparado para este fin, en la casa del maestro. El altar es a su vez decorado con lámparas de colores, fotos, cintas, etc., que acentúan su carácter sagrado.

El principio y el final de estos rituales parecen ser particularmente importantes, ya que se caracterizan como «ritos de paso» (Van Gennep 1978), con miras a la transposición entre los diferentes espacios-tiempos. Los ritos alrededor de la retirada del estandarte del altar marcan el paso del espacio-tiempo cotidiano hacia el espacio tiempo mito-mágico de los Reyes magos, así como tratan de dar protección espiritual a los miembros del grupo. Es también en este momento en el cual se realizan ri- 




Figura 1. Portaestandarte llevando el estandarte. (Fotografía de Daniel Bitter).

tos especialmente dedicados a los payasos ya que se cree que éstos necesitan más protección que el resto, debido a su conexión con fuerzas negativas y peligrosas. Durante estos rituales, los, payasos sin las máscaras, se acercan al altar y encienden cirios en el suelo a sus ángeles de la guarda ${ }^{2}$. Estos procedimientos se realizan con el sonido de instrumentos musicales realizados por los foliões ${ }^{3}$. La música juega un papel central en estos rituales, pues proporciona formas de interacción entre los foliões, devotos y participantes. Los versos rimados y cantados por el maestro (las profecías) son repetidos por el coro de voces que anuncia los gestos que la portaestandarte y otros foliões deben llevar a cabo de forma sincronizada. Los foliões salen a la calle y el estandarte es el último en abandonar la casa. Hay una relación jerárquica clara entre el estandarte y los foliões, ya que el primero inspira un gran respeto y reverencia. El estandarte permite ingresar al espacio tiempo mito-magia de los Magos y también pretende dar protección espiritual a los miembros del grupo.

Al salir de la casa del maestro, el estandarte entra en circulación por las vías públicas de la localidad hacia las casas de los devotos, siempre regresando al altar al final de cada día de viaje. Puesto que el estandarte abandona el altar y comienza a circular, adquiere una dimensión pública, dado que está a la vista de los transeúntes y puede ser tocado por la gente. En este espacio-tiempo especial, el estandarte también demarca jerarquías ya que su recepción es un privilegio particular para las pocas personas más importantes o más estrechas a los foliões. En la Figura 1 se puede observar al portaestandarte llevando el objeto ritual por las calles de Candelaria.

\footnotetext{
2 Mientras que las velas encendidas para el estandarte se encuentran en un terreno elevado, las velas destinadas a los payasos permanecen en el suelo. Esta oposición parece ser particularmente significativa.

3 Se presenta de una manera muy solemne, con ritmo cuaternario, relativamente lento, cadencioso y marcado por el impulso de las bandas militares. Los instrumentos son acordeón, guitarra, viola, cavaquinho y varios instrumentos de percusión.
} 


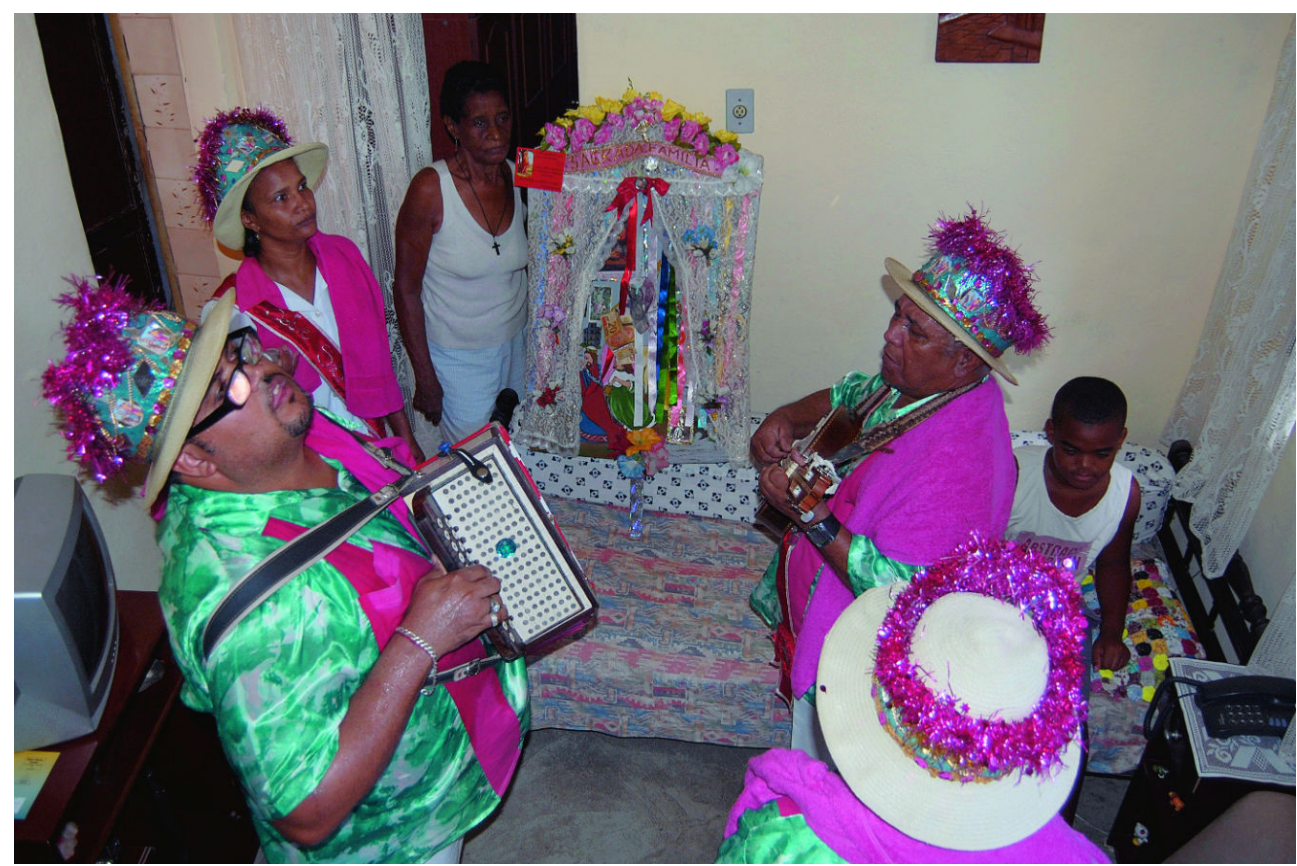

Figura 2. Ritual en la casa. (Fotografía de Daniel Bitter).

La folia realiza una secuencia básica de acciones durante una visita a una casa, que incluye la llegada, distribución de bendiciones, comida, performance del payaso, dádivas y despedida, y se configura como un «proceso ritual» (Turner 2005) que se desarrolla a lo largo del tiempo. En la puerta de la casa de un devoto, el estandarte pasa a manos de los miembros de la familia que vienen a recibir al grupo religioso ${ }^{4}$. Todos los gestos y movimientos del cuerpo que implican la manipulación del estandarte por lo general son moderados, en contraste, por ejemplo, con los gestos agitados de los payasos, personajes enmascarados profundamente ambiguos. El estandarte es a menudo reverenciado y besado por los residentes de las casas, quienes por lo general lo mantienen en sus manos mientras se desarrolla el canto en el interior de la vivienda donde la familia se reúne para recibir bendiciones (Figura 2). Los versos rimados y las canciones que los acompañan también tienen la función de solemnizar los intercambios rituales. Una señal sonora marca el final del canto, para que todos puedan descansar y compartir una breve comida antes de la performance de los payasos. Entonces, el estandarte se coloca en una silla, una mesa o en una cama y es, a menudo, objeto de muchos contactos corporales por parte los habitantes de una casa. El maestro generalmente retira cintas de seda de color del estandarte y se las ofrece a los moradores. Inversamente, algunas veces, los últimos le proporcionan las cintas y otros objetos al estandarte, en agradecimiento por las bendiciones recibidas. Las cintas están estrechamente identificadas con ciertos santos católicos o entidades de tradiciones religiosas afrobrasileñas, de acuerdo a sus colores. Por ejemplo, la cinta roja

\footnotetext{
4 El estandarte media entre la calle y la casa, a través del establecimiento de un pasaje ritual (Van Gennep 1978).
} 


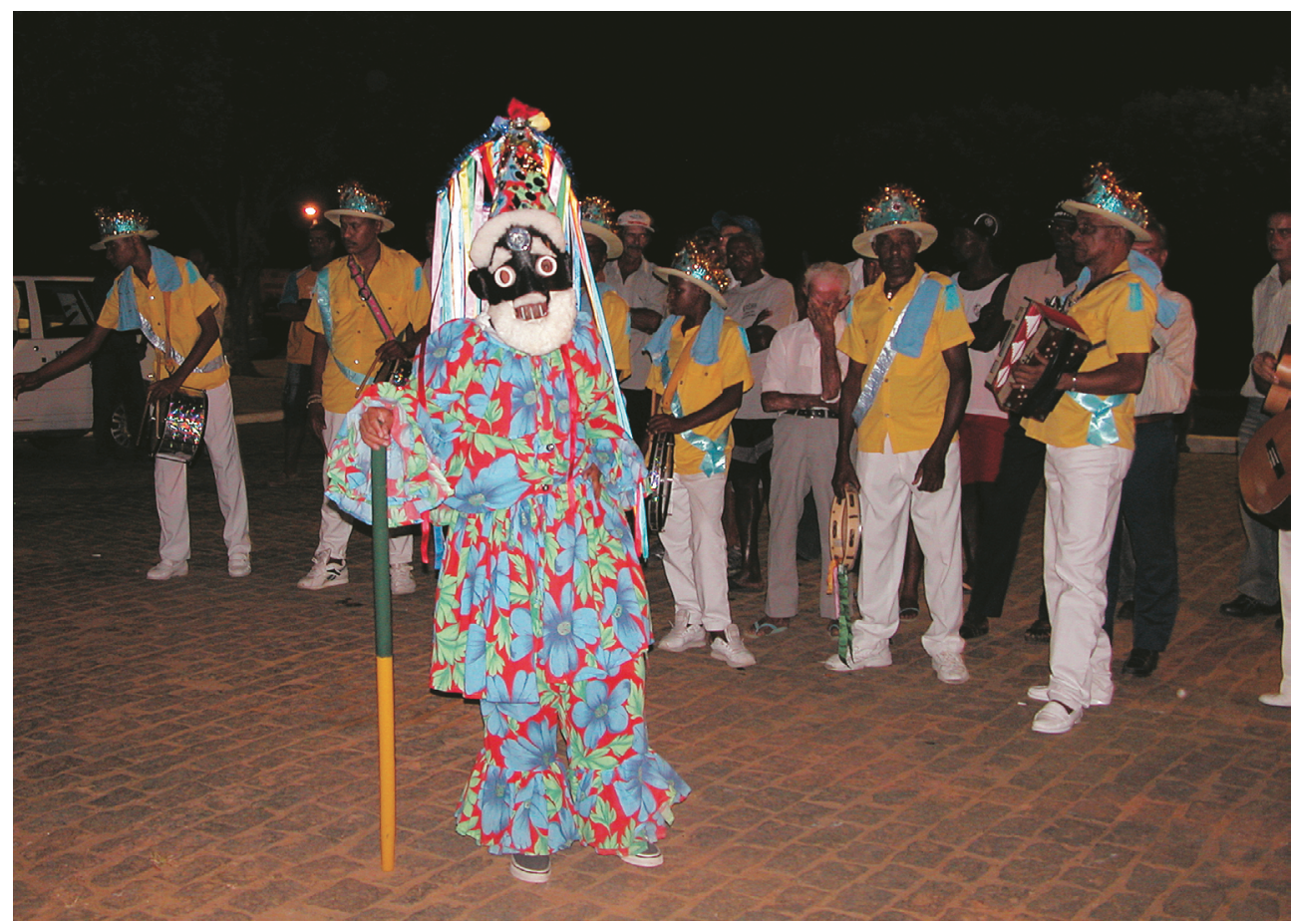

Figura 3. Performance del payaso. (Fotografía de Daniel Bitter).

puede estar relacionada con San Sebastián u Ogum ${ }^{5}$. Recibir una cinta de colores, es un hecho muy significativo, sentido como un regalo hecho por la propia divinidad.

También se acostumbra a llevar el estandarte a los lugares más recónditos e íntimos de la casa. Para los moradores, este gesto parece ser una forma de santificar, purificar o alejar a los malos espíritus. La casa es foco de una transformación significativa en este momento. Es, después de todo, en la casa donde se tejen redes sociales significativas, lo que explica la importancia de los ritos a ésta dedicados.

Los payasos permanecen fuera de la casa, asustando a los niños y transeúntes en la calle con sus máscaras grotescas, esperando el momento de su exposición lúdica, que llaman brincadeira (Figura 3). Su performance se lleva a cabo casi siempre en la calle o en el patio, pero también puede tener lugar dentro de la residencia, debido a la escasez de espacio. En este caso, su entrada a la casa se hace de forma gradual y luego de haberlo solicitado al devoto que recibe la folia. A menudo, el estandarte es retirado del espacio en el cual el payaso realizará su presentación. En otras ocasiones, sólo se cubre con un pañuelo, lo que indica que la visibilidad del estandarte es un camino privilegiado para la manifestación de sus poderes. Aun así, la presencia del estandarte y su proximidad son aspectos que garantizan su eficacia, ya que los payasos no deben acercarse demasiado a éste, a menos que estén sin sus máscaras, pero tampoco pueden distanciarse tanto, ya que requieren su protección. La razón

\footnotetext{
5 Ogum (Ògún) es un orixá representado como temible guerrero, violento e implacable, dios del hierro, de la metalurgia y de la tecnología; protector de herreros, agricultores, cazadores y de todos los profesionales que de alguna forma se ocupan de los metales.
} 
de este peligro potencial y estas prohibiciones se puede encontrar en exégesis mitológicas en las cuales el payaso es representado negativamente, como el Diablo o Herodes, rey de Judea, o sus soldados que han perseguido al niño Jesús para matarle. Este personaje también es asociado a $\mathrm{Exu}^{6}$, lo que demuestra la fuerte influencia de los cultos afro-brasileños entre los foliões de reis, particularmente en el estado de Río de Janeiro.

El payaso declama versos memorizados o improvisados en el acto, de acuerdo con las circunstancias del momento. Su carácter es muy cómico y con frecuencia el público e incluso el propio dueño de la casa son objeto de sus chistes. Su juego es divertir a la audiencia y aprovechar el dinero ofrecido y tirado al suelo por el público. Por lo tanto, las ganancias dependen de una negociación continua entre el payaso y público, quienes intercambian versos o acrobacias por dinero. Es importante señalar que, a diferencia de las donaciones que se ofrecen al estandarte, totalmente asignadas para financiar la fiesta, el dinero presente en la performance del payaso es generalmente usado para su propio disfrute.

Al final de la presentación de payasos, los foliões se reúnen de nuevo dentro de la casa, para cantar agradecimientos. Aquí es donde los residentes suelen hacer ofertas en efectivo al estandarte. Los billetes son sujetados al velo o a las cintas por la portaestandarte. Aquí el estandarte lleva a cabo una de sus muchas mediaciones, en este caso, operando una especie de purificación del dinero recibido ${ }^{7}$. Signo por excelencia de los intercambios mercantiles, el dinero se convierte en un regalo a través de la mediación del estandarte.

Versos de despedida anuncian que el estandarte va a marcharse en busca de otra casa y, de nuevo, gestos y cantos rituales se realizan de manera que el estandarte vuelva a las manos de la portaestandarte a la salida del grupo. Después de muchos días de arduas jornadas que pueden exceder doce horas continuas por día, los foliões deben decirle adiós al estandarte de modo que sea nuevamente llevado al altar y para que vuelva a circular el próximo año. En Candelaria, el ritual de entrega da estandarte se lleva a cabo en la casa del maestro, en medio de una intensa emoción, delante del altar, donde foliões y payasos son llamados por su nombre a través de cantorías, para despedirse del estandarte. En esta condición, cada uno a su vez, se aproxima al estandarte, se quita el sombrero coronado y se arrodilla para darle un beso. Entonces la portaestandarte bendice al folião pasando el estandarte por encima de su cabeza. Los payasos son los últimos en decir adiós y se acercan al estandarte de rodillas y sin sus máscaras. La bendición realizada a los payasos adquiere aspectos particulares: éstos se acuestan en el suelo, boca abajo y la portaestandarte les pone el estandarte sobre la espalda, realizando una cruz en movimiento. Para los foliões este gesto es la expresión de disculpa que los payasos deben al estandarte, a los santos. Es, después de todo, un ritual de conversión religiosa. El payaso, en principio asociado con el mal, está sujeto a una inversión simbólica de fondo moralizante.

\footnotetext{
Exu es una entidad del panteón de orixás petenecientes a los cultos yoruba y jejê. Es representado en las narrativas míticas como una entidad que subvierte las conductas sociales más generales. Es conocido como mensajero por mediar la relación entre humano y divino. Exu está ligado a la vitalidad, a la fuerza, a la protección. Con los procesos de sincretismo entre estas religiones y el catolicismo europeo, Exu pasó a ser visto negativamente y a ser asociado a la figura del diablo.

7 De hecho, lo que parece caracterizar más profundamente al estandarte es, sobre todo, la capacidad de llevar a cabo mediaciones entre diferentes dominios, tales como el cielo y la tierra, alto y bajo, pasado, presente y futuro, vivos y muertos, visible e invisible, etc.
} 


\section{El estandarte, sus usos y significados}

El estandarte consiste en un soporte, por lo general con aspecto muy atractivo, diseñado para mostrar imágenes relacionadas con los magos, la Sagrada Familia, San Sebastián y otros santos. Las imágenes se cubren con muchas cintas de colores, adornos navideños y un velo protector. También tiene un eje central para manejarla y cuya función simbólica es mediar la relación con el plano trascendente. El estandarte se mueve a lo largo de las procesiones llevadas a cabo en las folias de reis, siempre dirigido por la portaestandarte, práctica que implica conocimientos específicos y gestos rituales altamente codificados.

Los estandartes por lo general tienen una «vida» larga, perenne, que llega a muchas décadas. A diferencia de la máscara del payaso, mucho más efímera, el estandarte tiene sus raíces en el tiempo, está hecho para durar, lo que es un aspecto que polariza el estandarte y la máscara y sus significados. Aun así, los estandartes son perecederos, y de vez en cuando necesitan ser reformados o reemplazados, lo que sólo puede hacerse a la luz del fundamento ${ }^{8}$. En este sentido, Weiner sugiere que «although the passage of time may encrust an object with patina or contributes for its fraying, these alterations heighten rather than diminish the object's value» (1992: 39). Puesto que es perecible, el estandarte debe ser restaurado o reemplazado. El maestro de Folia Sagrada Familia, ayudado por la portaestandarte, hace anualmente una reforma en el estandarte, lo desarma y cambia ciertas partes, tales como cintas, velo, flores etc.

En 2010, cuando retorné al trabajo de campo en Manguera, tuve la oportunidad inusitada de observar el procedimiento de desarme del estandarte y pude grabar fotográficamente sus diversas etapas, fuera del ciclo festivo. Eliane, la portaestandarte, inició el procedimiento extrayendo el velo del estandarte. A continuación, procedió a la extracción de flores, cintas de seda y otras partes, las cuales depositó cuidadosamente en una bolsa. Luego de este proceso, Eliane retiró la cubierta que contiene la imagen pintada de los Reyes magos y que cubre la estructura de madera. Ante mi presencia, Eliane sonrió e hizo el siguiente comentario, en broma: «Ahora vas a ver el estandarte desnudo ${ }^{9}$. Eliane tuvo dificultades al sacar la cubierta del estandarte, como si fuera un traje femenino que estaba muy justo e hizo el siguiente comentario: « $\mathrm{A} A \mathrm{~h}$ ! no me acordaba que esta cubierta era así de estrecha. Creo que este estandarte ganó unas cuantas libras ¿eh?». Estas observaciones demuestran un dato notable sobre el cual he llamado la atención a lo largo de este texto. El estandarte es tratado como una «persona», y más que eso, como una persona especial.

Al final del proceso de desarme sólo quedaba una estructura de madera, el esqueleto del estandarte, que no debe normalmente ser visto por el público. El maestro Hevalcy dijo que reformaría la estructura, reforzándola. También señaló que la cubierta de tela que contiene el modelo pintado debe ser cuidadosamente lavada y antes de vestir de nuevo la estructura de madera, es necesario darle la cubierta a un sacerdote para que la bendiga. De acuerdo con el maestro, no se debe reutilizar materiales en el mantenimiento del estandarte. Cintas de seda de colores, por ejemplo, deben ser

\footnotetext{
8 El fundamento, categoría nativa de gran importancia, se refiere al conocimiento religioso que respalda las acciones rituales de los foliões de reis. En general, se considera como un conocimiento mítico y divino.

9 João Vasconcelos reporta numerosos casos de fiestas y festivales portugueses en los cuales la desnudez de una imagen de la rueda de giro puede considerarse un hecho escandaloso. El autor también muestra que a menudo la preparación de ciertas imágenes para una procesión es una actividad que debe ser realizada exclusivamente por mujeres (Vasconcelos 1998).
} 
siempre nuevas y estar almacenadas en envases inviolables. La explicación de este cuidado me la dio con las siguientes palabras: «se ha utilizado, se lleva el sudor de la persona. Las cintas tienen que estar guardadas en envases para no correr el riesgo de que alguien las haya tocado o utilizado». Como se puede ver, se introduce aquí el tema de la «impureza» y sus fechorías contagiosas (Douglas 1976). Estos aspectos recuerdan estrechamente las descripciones de Malinowski sobre los procedimientos rituales en la construcción de canoas trobriand. El autor escribe:

«cualquier tipo de profanación derivada del contacto de alguna sustancia impura con el tronco de la canoa, puede volverla lenta e inadecuada. Si alguien anda o permanece de pie sobre del tronco de una canoa, el resultado será igualmente desastroso» (Malinowski 1976: 118, traducción libre del autor).

Por otro lado, diversos materiales se pueden reutilizar en la fabricación de uniformes de los payasos, así como en sus máscaras. Todos estos procedimientos rituales y el fundamento en el cual se basan, garantizan la validación de poderes y significados atribuidos a los estandartes, lo que permite, finalmente, su permanencia y continuidad en el tiempo. Sin embargo, los estandartes también se pueden sustituir de maneras que sorprenderían a cualquier persona que considerase que son los atributos intrínsecos a los objetos los que los hacen efectivos. Un ejemplo podría ser instructivo. El maestro Antonio de la Folia Estrela Belém do Norte de São Fidelis, Río de Janeiro, ha fabricado su nuevo estandarte hace unos años. Le pedí que me mostrara el antiguo estandarte, que había sido guardado sin ningún cuidado, en medio de otros objetos antiguos en un garaje. No hay duda de que esto es sólo una reminiscencia de estandarte, totalmente separado del sistema vivo de los cambios y mediaciones a las cuales por lo general está vinculado. En este caso, el estandarte fue descartado deliberadamente y algunas de sus partes fueron utilizadas en la fabricación del nuevo estandarte, a su vez, investido de los poderes que emanaban del anterior. A partir de este ejemplo, es posible sugerir que los objetos son, en última instancia, transitorios, al igual que las personas. Lo que permanece son las ideas, visiones del mundo, en una palabra, el fundamento. Sin embargo, a menudo la transmisión de ciertos conocimientos e ideas no exime la presencia material de los objetos, los cuales sirven como mediadores sensibles, como ya ha sido señalado por Durkheim en relación con el principio totémico (Durkheim 1989).

Aún mucho más se podría abordar sobre el estandarte, sus usos y significados, sin embargo, es esencial remitirnos a la relación que se establece con otro objeto ritual: la máscara.

\section{La máscara y su liminalidad}

A la señal del toque acelerado del acordeón y la percusión, una extensa rueda de excitados espectadores se forma, esperando ansiosamente la entrada del payaso, personaje enmascarado de la folia de reis. El payaso le pide permiso al dueño de la casa para iniciar su presentación espectacular, que todos denominan como brincadeira y en la cual este personaje de apariencia y gestos grotescos declama versos rimados y cómicos, conocidos como el chula.

Como se ha señalado anteriormente, el contraste de la actitud entre payasos y foliões es muy llamativo. Mientras que los foliões se caracterizan por la formalidad, los 
payasos están más vinculados con la dimensión lúdica, creativa y transgresora del ritual. Existe un fuerte contraste entre payasos y foliões, así como entre la máscara y el estandarte, reforzado por otros contrastes simbólicos relacionados como entre el exterior y el interior, seria y cómica, alta y baja, etc. De hecho, la actitud de los payasos es, en muchos sentidos, lo opuesto a los foliões, como ha sido señalado por Brandão (1977) y Frade (1997). Estos contrastes terminan produciendo un equilibrio entre los elementos lúdicos, creativos y formales. Tal oposición, sin embargo, es totalmente relativa y complementaria.

El payaso se puede definir como un ser liminal, marginal, que vive de su propia indefinición. Según lo propuesto por Turner en su definición de la liminalidad, «No estamos ante contradicciones estructurales cuando hablamos de liminalidad, sino de lo que esencialmente es no estructurado (de lo que es, al mismo tiempo, no estructurado y pre-estructurado)» (2005: 142). Las personas liminales están dotadas de una invisibilidad estructural, que, en el caso de los payasos, es, en cierto modo, también física, dado el uso de la máscara. Esto hace que no sean obligados a cumplir con ciertas normas sociales, lo que los coloca en estrecha relación con los poderes no sociales o asociales de la vida y la muerte. Como el propio Turner escribe: «están muertos hacia el mundo social, pero vivos para el mundo asocial» (1982: 27). Los payasos, sin embargo, están vinculados no sólo a las nociones de peligro y desorden, sino que también pueden ser vistos como divulgadores de ideas no oficiales que apuntan a un orden cósmico diferente. En esta visión cosmológica predomina la heterogeneidad, yuxtaposición de esferas y dimensiones dispares y con frecuencia separadas así como la negación de ciertas convenciones (Bakhtin 1993).

La ambigüedad en ciertos contextos, se interpreta como una fuente constante de peligro que amenaza el «orden» y la estabilidad. Normas relacionadas con la «contaminación», por ejemplo, están fuertemente asociadas con cosas y situaciones ambiguas, según Mary Douglas (1976). Como la autora señala, «la reflexión sobre la suciedad implica la reflexión sobre la relación entre el orden y el desorden, ser y no ser, forma y no forma, vida y muerte» (Douglas 1976: 17). Para Douglas, la preocupación con las impurezas se une directamente a cuestiones relacionadas con el ordenamiento del mundo.

Al mantener contacto con fuerzas peligrosas, los payasos necesitan llevar a cabo numerosos preparativos rituales antes de vestirse y ponerse sus máscaras. Observé al payaso conocido como Guerrero, por ejemplo, moviendo varias veces su uniforme entre las piernas, haciendo una figura en forma de ocho alrededor de los pies. $\mathrm{Me}$ explicaron este procedimiento como gestos de protección contra acciones maléficas que se dicen frecuentes en las folias de reis, cuando los payasos también están presentes y pueden intensificar los conflictos, las amenazas y las rivalidades.

También ayuda a caracterizar la ambigüedad y la ambivalencia de este personaje, la idea de que el payaso necesita, más que cualquiera, la protección de los poderes divinos del estandarte. $\mathrm{Si}$, por un lado, el payaso evita acercarse mucho al estandarte, por otro, no puede distanciarse demasiado de éste. De acuerdo con el payaso llamado Gigante, esta distancia no debe ser superior a 50 metros, bajo riesgo de perder la protección del estandarte.

Como indica el maestro Hevalcy y muchos foliões, los payasos desaparecen o son severamente castigados cuando se desvían del estandarte y del grupo. Esto apunta al hecho de que los objetos producen efectos eficaces sobre los individuos y sus relaciones. La gente y las cosas están inextricablemente unidas en la zona circun- 
dante. El payaso es un «símbolo dominante» sujeto a una regresión entre sus polos de significación, lo que está directamente vinculado a la presencia o ausencia de la máscara en las diversas etapas de los rituales. Como ya he mencionado, el payaso se asocia generalmente con representaciones negativas, como los soldados de Herodes, que persiguieron al niño Jesús. Sin embargo he sostenido que durante los rituales hay un momento en particular durante el cual los payasos deben quitarse las máscaras y pasar por un rito de conversión simbólica. Se trata de una performance acompañada de un comentario moralizante con el objetivo de confirmar una cierta concepción del orden cosmológico. El payaso, en cierto modo, reencarna el tema fáustico de pacto con fuerzas negativas, diabólicas y de conversión, como en el caso de San Cipriano, el santo brujo (Ferreira 1992).

Hay otros momentos en los que el payaso debe retirar la máscara. Por ejemplo, cuando se recitan versos de contenido moral y religioso. En esta condición, el payaso puede recitar versos ante el estandarte. En la mayoría de los casos, sin embargo, el payaso aparece enmascarado, lo que requiere un cierto cuidado para evitar demasiada proximidad al estandarte y a los demás foliões.

El conjunto de acciones rituales produce cambios simbólicos reflejados en la experiencia concreta de los sujetos. Estas acciones se desarrollan en la forma de un «proceso ritual» e incluyen quitarse la máscara, caminar de rodillas, desplazarse en el espacio, postrarse ante del estandarte. Me gustaría añadir que todos estos gestos se insertan en un contexto ritual más amplio que involucra muchos otros elementos como la música, palabras, sentimientos obligatorios, presencia de la audiencia, etc. En este sentido, también tengo en cuenta la sugerencia de Schieffelin:

«...rituals gain their effectiveness by being performed. It is through participation in ritual singing and dancing, or through viewing dramatic presentations of sacra, emblems and masks, or through being subjected to painful ordeals that participants come to see symbolic representations as having a force of their own» (Schieffelin 1985: 722).

La máscara, por lo tanto, es eficiente produciendo transformaciones y en el contexto de la performance del payaso parece hacer un intercambio entre personalidades, creando un «otro», un «doble» a través de procesos miméticos. En cualquier caso, el efecto completo de la máscara sólo puede lograrse cuando es utilizada y puesta en movimiento por una persona. Por cierto, hay que añadir que a menudo las máscaras están relacionadas con un vestido llamado farda, que por lo general cubre todo el cuerpo. Todo esto indica que la máscara y la ropa son una extensión corporal o un «segundo cuerpo», un «doble» de la persona. Estos objetos se ven como inseparables de sus propietarios y sus cuerpos. Las máscaras son intransferibles, por lo que se evita hacer uso de máscaras ajenas. Hay muchos relatos dramáticos de casos en los que se utilizaron indebidamente las pertenencias de otro payaso. Por esta razón, no solamente los payasos, sino también los foliões deben ser extremadamente cuidadosos con sus objetos rituales (instrumentos, sombreros, máscaras), ya que éstos pueden ser objeto de apropiación indebida por parte de foliões de otros grupos y utilizados como mediadores de procedimientos mágico-religiosos.

Como el maestro Hevalcy me informó, una pequeña distracción puede permitir que alguien corte cintas de la máscara o instrumentos para su uso en brujería, con la posibilidad de producir efectos desastrosos. Lo que es evidente, es que estos objetos están rodeados de normas y reglamentaciones. En el caso de la máscara, 


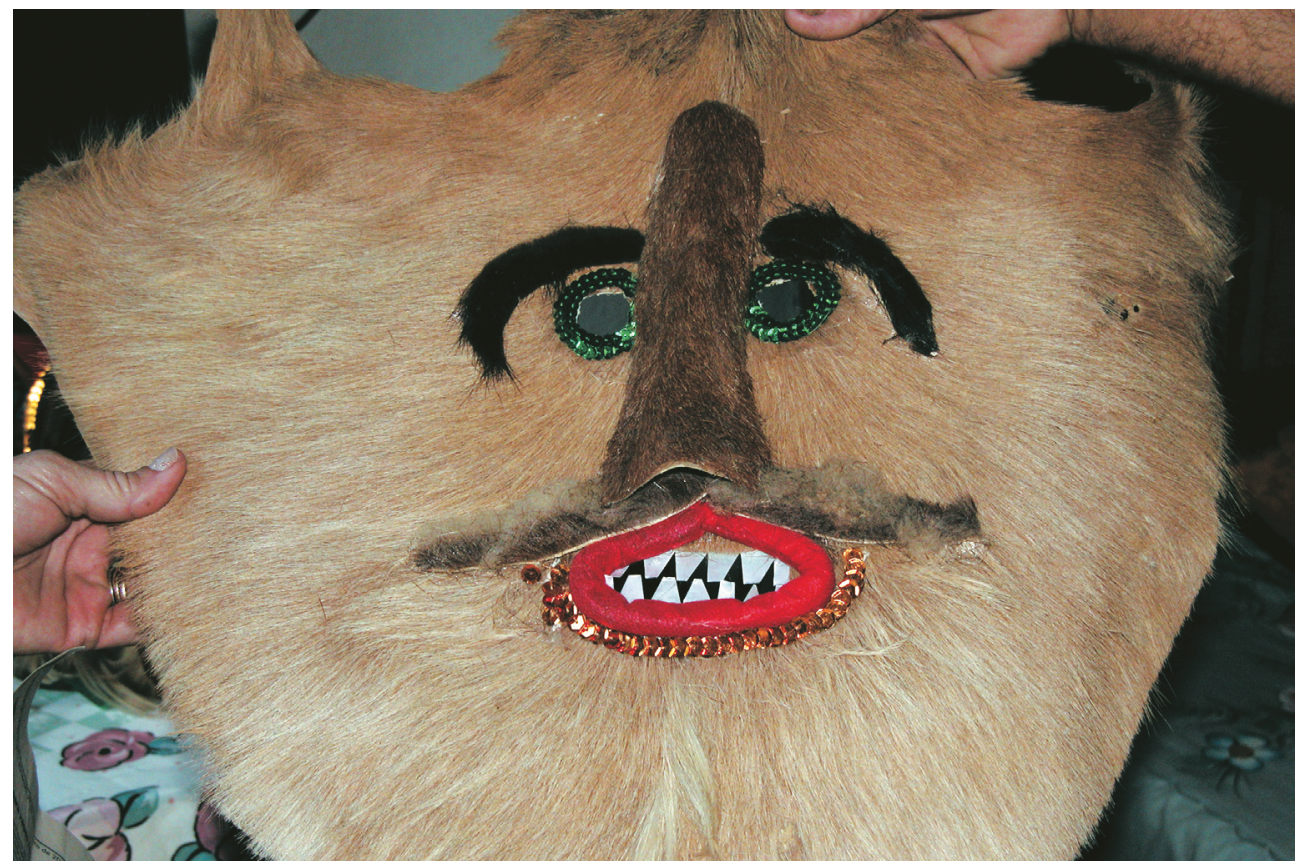

Figura 4. Máscara confeccionada en cuero. (Fotografía de Daniel Bitter).

es un objeto que debe evitarse, ya que contamina a quien la toca deliberadamente. En contraste, el estandarte es foco de intenso contacto físico. El uniforme y la máscara son, sin embargo, inseparables de sus propietarios, pues son medios eficaces para llevar a cabo procedimientos «mágico-religiosos», y por lo tanto deben ser cuidadosamente guardados. A este respecto, he de señalar que cuando muere un payaso, su uniforme y máscara se consideran, a menudo, como residuos que deben ser eliminados adecuadamente. Esto es realizado por la familia, que los sumerge en un río de manera que el agua se los lleve, sin dejar rastro de su presencia, un procedimiento que es similar a los llamados despachos ${ }^{10}$ realizados en determinados cultos afro-brasileños.

En su diversidad de formas, materiales y estilos, las máscaras tienen en común la apariencia grotesca, deforme y monstruosa, tal como se muestra en la Figura 4. Las máscaras son a la vez aterradoras y cómicas. Estas características son evidentes en la exageración formal de ciertas partes como la boca, los dientes, la nariz, los ojos y oídos. Hay un énfasis en estas partes y en los orificios, signos visibles de la mediación del cuerpo con el mundo, del cuerpo individual con el cuerpo colectivo (Douglas 1976). Para la autora, los orificios representan los puntos de mayor vulnerabilidad, donde se expulsan sustancias marginales. Como he señalado anteriormente, la máscara y el uniforme del payaso se consideran márgenes corporales al estar en contacto directo con el cuerpo, con su personalidad, y son entendidos como fuentes de contaminación y magia.

\footnotetext{
${ }^{10}$ Término utilizado para designar de modo genérico cualquier ofrenda en las religiones de los orixás.
} 


\section{Consideraciones finales}

Busqué explorar a lo largo de este texto la relación que tienen las personas con ciertos objetos en un contexto particular. El estandarte y la máscara parecen jugar un papel clave en rituales de folias de reis y el análisis de sus usos y significados parece indicar, después de todo, el sentido que los foliões y devotos dan a sus relaciones de intercambio.

Lo que parece evidente a partir de los hechos etnográficos del presente texto, es que estos objetos producen una diversidad de personas y relaciones, y parecen estar vinculados a una moralidad de las acciones. Por lo tanto, el ritual produce la experiencia, lo que permite la visualización de ciertos conocimientos que fuera de éste no serían percibidos. A través de los ritos y sus sistemáticas se articulan formas de autoconocimiento en las que se inscriben dimensiones objetivas y subjetivas de la cultura. Como Valerio Valeri finalmente escribe:

«Esta sutil dialética entre liberdade e regra, entre individualidade e forma coletiva, torna-se então um poderoso esquema imaginário para a experiência da relação entre a realidade e o desejo, entre o social e o individual. A vitória do indivíduo sobre a norma na vitória da norma sobre o indivíduo é uma experiência agradável, de natureza essencialmente estética» (1994: 347).

\section{Referencias}

Bakhtin, Mikhail. 1993. A cultura popular na Idade Média e no Renascimento: o contexto de François Rabelais. São Paulo y Brasília: Hucitec, Edunb.

Bourdieu, Pierre. 1996. «Marginalia. Algumas notas adicionais sobre o dom». Mana 2 (2): 7-20. https://doi.org/10.1590/S0104-93131996000200001.

Brandão, Carlos Rodrigues. 1977. A folia de reis de Mossâmedes. Río de Janeiro: Fundação Nacional de Artes.

Douglas, Mary. 1976. Pureza e perigo. São Paulo: Perspectiva.

Durkheim, Émile. 1989. As formas elementares de vida religiosa: O sistema totêmico na Austrália. São Paulo: Paulus.

Ferreira, Jerusa Pires. 1992. O livro de São Cipriano: Uma legenda de massas. São Paulo: Editora Perspectiva.

Frade, Cáscia. 1997. O saber do viver. Redes sociais e transmissão do conhecimento. Tesis doctoral. Río de Janeiro: Pontifícia Universidade Católica do Rio de Janeiro.

Malinowski, Bronislaw. 1976. Argonautas do Pacifico Ocidental. Um relato do empreendimento e da aventura dos nativos nos arquipélagos da Nova Guiné Melanésia. São Paulo: Abril.

Mauss, Marcel. 2003. «Ensaio sobre a dádiva», en Sociologia e antropologia, pp. 185-314. São Paulo: Cosacnaify.

Schieffelin, Edward L. 1985. «Performance and the Cultural Construction of Reality». American Ethnologist 12 (4): 707-724. https://doi.org/10.1525/ae.1985.12.4.02a00070.

Turner, Victor. 1982. From Ritual to Theather. Nueva York: PAJ Publications.

- 2005. Floresta dos símbolos. Niterói: Edital Universidade Federal Fluminense.

Valeri, Valerio. 1994. «Rito», en Enciclopédia Einaudi 30. Religião-rito, pp. 325-359. Lisboa: Imprensa Nacional, Casa da Moeda.

Van Gennep, Arnold. 1978. Os ritos de passagem. Petrópolis: Vozes. 
Vasconcelos, João. 1996. Romarias I. Um inventário dos santuários de Portugal. Lisboa: Olhapim.

Weiner, Annette. 1992. Inalienable Possessions: The Paradox of Keeping-While-Giving. Berkeley: University of California Press. 